Jurnal Pendidikan Biologi 9 (2) (2020) 1 - 9
Jurnal Pendidikan Biologi
Journal of Biology Education
elSSN: 2502-3810 $\mathrm{pISSN}$ : 2086-2245

\title{
Capaian Aspek Kompetensi Sains Siswa SMA dengan Pembelajaran Model Problem-Based Learning dan Cooperative Learning Tipe STAD
}

\author{
Trisna Amelia ${ }^{1, *}$, Nevrita $^{1}$, Desi Rahmatina ${ }^{2}$ \\ ${ }^{1}$ Program Studi Pendidikan Biologi FKIP Universitas Maritim Raja Ali Haji, Jalan Politeknik Senggarang, \\ Tanjungpinang, Kepulauan Riau, Kodepos 29115 \\ ${ }^{2}$ Program Studi Pendidikan Matematika FKIP Universitas Maritim Raja Ali Haji, Jalan Politeknik Senggarang, \\ Tanjungpinang, Kepulauan Riau, Kodepos 29115
}

\section{INFO ARTIKEL}

Histori Artikel

Received 23 Oktober 2019

Revised 6 Januari 2020

Accepted 25 September 2020

Published 30 September 2020

\section{Keywords:}

Problem-based Learning, Cooperative Learning STAD type,

Science literacy, Science competence, Comparative study

\begin{abstract}
Science literacy is an essential element of science and technology learning. The mastery of science literacy drives people being competitive and worth employed, especially in the workplace where an employee is expected to be innovative. Globally the mastery of society's science literacy of Indonesian students was still low. Science literacy consists of 4 dimensions, namely context, science competence, knowledge, and science attitude. The science competency dimension becomes important to be achieved by the students as an indicator of the achievement of science literacy. Related to improving science literacy through components of learning strategy, based on various relevant research, in SMA Negeri 1 Tanjungpinang has been conducted a study to compare the achievement of science competency with Problem-based learning and Cooperative Learning (STAD type). To test whether there is a significant difference in the average level of science competency scores between the PBL class and the CL-STAD class in SMA 1 used Mann-Whitney test which shows a significant value of $0.000<0.05$. These results show that there is a significant difference in the average level of science competency of the students X IPA class with the implementation of the PBL and CL-STAD in SMA 1 Tanjungpinang. The achievement of science competency in PBL class is higher than the achievement in CL-STAD class based on 3 aspects, namely: identifying scientific issues, explaining scientific phenomena, and using scientific evidence.
\end{abstract}

Copyright (C) 2020 Universitas Negeri Medan. Artikel Open Access dibawah lisensi CC-BY-4.0 (https://creativecommons.org/licenses/by/4.0)

How to Cite

Amelia, T., Nevrita, \& Rahmatina, D. (2020). Capaian Aspek Kompetensi Sains Peserta Didik dengan Pembelajaran Model Problem-Based Learning dan Cooperative Learning Tipe STAD. Jurnal Pendidikan Biologi, 9(2), 1-9.

\section{PENDAHULUAN}

Literasi sains merupakan elemen penting pendidikan dalam ilmu pengetahuan dan teknologi modern di masyarakat. Literasi sains sangat penting untuk mengajarkan ilmu pengetahuan kepada semua warga negara, tidak hanya bagi mereka yang aktif terlibat atau 
memiliki pilihan karir di bidang sains saja (McPhearson, 2008). Terdapat banyak versi definisi mengenai literasi sains. AAS menjelaskan bahwa literasi sains dimaknai sebagai kapasitas untuk menjadi akrab dengan dunia ilmiah dan menghargai kesatuan di dalamnya, menyadari cara penting di mana matematika, teknologi, dan sains tergantung pada satu sama lain, memahami konsep dan prinsip utama ilmu pengetahuan, memiliki kapasitas untuk cara berpikir ilmiah, dan dapat menggunakan sains dan cara berpikir untuk tujuan pribadi dan social Ogunkola (2013). McDonald \& Dominguez (2005), mengatakan bahwa literasi sains meliputi konsep kunci dalam ilmu alam, serta bagaimana ilmu pengetahuan berkaitan dengan matematika, teknologi, dan upaya manusia lainnya, literasi sains juga mencakup pemahaman tentang sifat ilmu pengetahuan serta keterampilan penyelidikan seperti merancang eksperimen, mengumpulkan dan menganalisis data, dan menarik kesimpulan yang valid dari bukti.

Dalam referensi berbeda para pakar juga mendefinisikan literasi sains terfokus pada komunitas. Dia menjelaskan bahwa literasi ilmiah adalah fokus untuk 'menggunakan ilmu pengetahuan' dan bukan 'melakukan ilmu' yang berarti bahwa tidak perlu individu untuk berlatih sains sebagaimana yang ilmuwan lakukan, yang terpenting adalah bagaimana individu mampu memanfaatkan sains dalam kehidupan sehari-hari. Literasi sains diartikan sebagai kapasitas seseorang untuk memahami komponen ilmiah untuk diterapkan dalam masalah publik. Berbagai definisi mengenai literasi sains pada prinsipnya sama-sama menyoroti bahwa literasi sains adalah komponen penting dalam pendidikan sains yang membantu individu mampu menyikapi berbagai persoalan dalam aspek-aspek kehidupan dengan menyandarkan kepada konsep, prinsip dan aplikasi sains (Ogunkola, 2013).
Menyoroti arti penting literasi sains, Heller (2005) terdapat alasan pentingnya memperhitungkan kompetensi ilmiah dan teknologi dalam standar minimum literasi dasar, di antaranya karena daya saing dan kelayakan kerja tidak dapat dipisahkan dari kapasitas individu untuk berpartisipasi aktif dan mempromosikan inovasi di tempat kerja. Alasan kedua adalah karena pada abad 21 sains dan teknologi telah memainkan peran yang semakin penting di banyak bidang kehidupan. Alasan penting berikutnya adalah banyaknya masalah sosial yang muncul di zaman sekarang yang melibatkan ilmu pengetahuan dan teknologi (Ogunkola, 2013). Sebagai upaya mengatasi masalah ini, masyarakat harus dapat berpartisipasi dalam diskusi dan proses pengambilan keputusan dengan pemahaman yang berkembang dengan baik tentang aspek ilmiah dan teknologi. Dunia membutuhkan masyarakat dengan keterampilan berpikir kritis, yang bisa secara mandiri mencari informasi untuk membangun opini yang rasional. Dengan kata lain, tingkat literasi sains yang tinggi membuat seorang individu menjadi kompetitif dan layak dipekerjakan, terutama di tempat kerja di mana seorang karyawan diharapkan menjadi inovatif.

Kenyataaannya, secara global penguasaan literasi sains masyarakat umumnya dan para peserta didik khususnya masih rendah (Schleicher, 2019). Berdasarkan hasil tes PISA 2018 yang sudah dirilis, Indonesia masih menduduki posisi 10 terbawah dari puluhan negara yang mengikuti tes ini. Skor penguasaan peserta didik Indonesia dalam hal sains masih belum beranjak ke level menengah. Indonesia memperoleh skor yang masih jauh di bawah skor Thailand, Malaysia, apalagi Singapura (Schleicher, 2019). Rendahnya skor literasi sains menjadi tugas besar pendidikan terutama pendidikan sains. Perlu adanya upaya yang serius untuk meningkatkan kualitas pembelajaran sains sehingga dapat menyentuh keaksara- 
an peserta didik tentang sains. Jika tidak ada upaya yang dilakukan untuk meningkatkan literasi sains, dampaknya akan dirasakan saat peserta didik sudah menjadi anggota masyarakat. Mereka akan menjadi bagian dari masyarakat yang tidak mendapatkan manfaat maksimal dari kemajuan sains dan teknologi (Ogunkola, 2013).

Dijelaskan oleh Organisation for Economic Cooperation and Development atau disingkat
OECD (2013), bahwa domain literasi sains terdiri atas aspek konteks, pengetahuan, kompetensi, dan sikap. Empat aspek ini memiliki keterkaitan yang erat dan saling kesinambungan dalam mengembangkan literasi sains secara seutuhnya. Aspek/dimensi kompetensi menjadi sentral yang harus dicapai oleh peserta didik sebagai indikator tercapainya literasi sains.

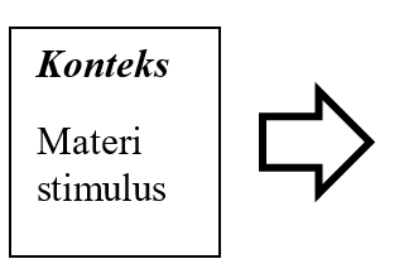

\section{Kompetensi}

1. Mengidentifikasi isu-isu ilmiah

2. Menjelaskan fenomena ilmiah

3. Menggunakan bukti ilmiah
Pengetahuan sains (Konten, prosedur, epistemik)

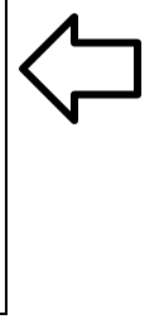

prosedur, epistemik)

Sikap (ketertarikan terhadap sains, menghargai kesatuan ilmu dalam sains, kepekaan terhadap lingkungan

Gambar 1. Bagan hubungan aspek-aspek literasi sains (OECD, 2013)

Gambar 1 menunjukkan bahwa domain konteks menjadi materi stimulus bagi siswa, kompetensi sains menunjukkan tanggapan siswa terhadap suatu pertanyaan atau isu yang disajikan, sedangkan pengetahuan sains merupakan inti dari soal yang disajikan. OECD (2013) menjelaskan kompetensi dalam literasi sains mengacu pada proses sains yang terlibat ketika menjawab suatu pertanyaan atau memecahkan masalah, seperti mengidentifikasi dan menginterpretasi bukti serta menerangkan kesimpulan. Termasuk di dalamnya mengenal jenis pertanyaan yang dapat dan tidak dapat dijawab oleh sains, mengenal bukti apa yang diperlukan dalam suatu penyelidikan sains, serta menarik kesimpulan yang sesuai dengan bukti yang ada (OECD, 2013). Kerangka ini dapat menjadi dasar untuk mengembangkan dan mengevaluasi kemampuan literasi sains dalam pembelajaran. Pengembangan kompetensi sains semestinya diintegrasikan dalam komponen pembelajaran, meliputi kurikulum, strategi pembelajaran, sumber belajar, serta media pembelajaran.

Pada tingkat sekolah, Grant dan Dianne (2011) menyarankan empat strategi untuk pendidik untuk meningkatkan keaksaraan ilmiah di kelas sains: mengidentifikasi topik ilmu yang menarik dan mengintegrasikan ke dalam ajaran topik dalam kurikulum, melibatkan peserta didik dalam membaca hasil penelitian, ajari peserta didik untuk membaca seperti para ilmuwan dan membimbing pelajar untuk mengevaluasi data. Penting bagi peserta didik untuk terbiasa dengan bagaimana mengevaluasi sumber data. Seperti para ilmuwan, peserta didik perlu tahu di mana untuk mengumpulkan data, bagaimana untuk mengumpulkan data, apa yang mewakili data dan juga berbagai sumber data.

Berdasarkan berbagai penelitian relevan, Problem-based learning merupakan salah satu 
model pembelajaran yang dapat memfasilitasi tercapainya kompetensi dasar dan metakompetensi bagi peserta didik (Aryulina dan Riyanto, 2016). Dalam PBL sekelompok peserta didik (biasanya 6-8) disajikan dengan masalah. PBL memang bukan satu-satunya strategi yang dinilai sesuai untuk mencapai hasil pembelajaran yang efektif khususnya untuk domain kompetensi yang kompleks. Namun, penelitian yang dilakukan salah satunya oleh (Strobel \& van Barneveld, 2009) diketahui bahwa PBL secara signifikan lebih efektif daripada pembelajaran konvensional untuk praktisi yang kompeten dan terampil serta untuk mendorong retensi jangka panjang dan keterampilan.

Sejalan dengan pergeseran paradigma pembelajaran dan perubahan kurikulum, PBL seyogyanya menjadi salah satu alternatif strategi yang diaplikasikan dalam pembelajaran. Berkaitan dengan penerapan pendekatan saintifik yang diutamakan dalam Kurikulum 2013, PBL menjadi sangat relevan untuk diaplikasikan. Kenyataannya dalam pembelajaran sains terutama biologi di sekolah menengah dikota Tanjungpinang, guru masih belum sepenuhnya menerapkan PBL di kelas. Berdasarkan observasi yang dilakukan pada pembelajaran biologi di SMA-SMA kota Tanjungpinang, guru masih memiliki kecenderungan menggunakan model pembelajaran kooperatif tipe STAD dalam pembelajaran. PBL kadang direncanakan dalam RPP, namun tidak diterapkan dengan ideal. Untuk mengetahui bagaimana PBL dalam memfasilitasi berkembangkan kompetensi sains peserta didik dibandingkan model pembelajaran yang guru lazim gunakan (CL-STAD), maka dilakukan studi komparasi di SMA Negeri 1 Tanjungpinang.

\section{METODE}

Penelitian dilakukan di SMA Negeri 1 Tanjungpinang dengan metode komparatif. Metode ini bertujuan untuk membandingkan suatu variable pada dua atau lebih kelompok sampel (Sugiyono, 2017). Dalam penelitian ini dilakukan pembandingan antara capaian kompetensi sains peserta didik dengan pembelajaran bermodel Problem-based Learning dan Cooperative learning tipe STAD. Untuk mendapatkan data perbandingan diberikan perlakuan pembelajaran PBL dan pembelajaran model CL-STAD pada dua kelas yang berbeda. Setelah proses pembelajaran pada materi Virus selama 2 kali pertemuan (6 x 45 menit) untuk pembelajaran biologi, dilakukan tes kompetensi sains (post-test) pada kedua kelompok peserta didik. Tes ini kemudian menjadi teknik pengambilan data dalam penelitian. Instrumen tes mengacu kepada tiga (3) aspek kompetensi sains, yaitu: kemampuan menggunakan bukti-bukti ilmiah, kemampuan menjelaskan fenomena ilmiah, dan kemampuan menjelaskan issu ilmiah. Selain instrument tes, juga digunakan lembar observasi untuk memastikan keterlaksanaan tiap tahapan $P B L$ dan CL-STAD. Populasi yang dilibatkan adalah peserta didik kelas X SMA Negeri 1 Tanjungpinang yang terdiri dari 2 kelas dengan masing-masing jumlah peserta didik 42 orang.

Data yang diperoleh dianalisis melalui teknik statistik deskriptif untuk mendeskripsikan capaian kompetensi sains dan statistik inferensial untuk mendeksripsikan perbandingan capaian kompetensi sains peserta didik pada kelas yang diajarkan dengan model $P B L$ dan $C L-S T A D$. Sebelum melakukan analisis komparatif, terlebih dulu dilakukan uji prasyarat (uji normalitas) untuk mengetahui normal atau tidak persebaran data hasil tes. 


\section{HASIL DAN PEMBAHASAN}

Penelitian yang dilakukan dengan dua (2) kali pertemuan pembelajaran menggunakan model PBL dan CL-STAD pada dua kelas berbeda, menghasilkan rerata skor capaian kompetensi sains di kelas yang belajar dengan model PBL lebih tinggi dibandingkan skor capaian literasi sains melalui pembelajaran CLSTAD. Melalui analisis statistik deskriptif diperoleh data sebagaimana pada Table 1 dan 2 yang memberikan gambaran detail distribusi frekuensi skor capaian literasi sains pada kedua kelas.

Tabel 1. Distribusi frekuensi skor capaian aspek kompetensi sains peserta didik dengan model PBL

\begin{tabular}{cccc}
\hline Interval Skor Kompetensi Sains & Jumlah Peserta didik & Frek kumulatif & Persentase \\
\hline $40-49$ & 1 & 1 & $2 \%$ \\
$50-59$ & 1 & 2 & $2 \%$ \\
$60-69$ & 1 & 3 & $2 \%$ \\
$70-79$ & 5 & 8 & $12 \%$ \\
$80-89$ & 12 & 20 & $29 \%$ \\
$90-100$ & 22 & 42 & $52 \%$ \\
\hline Total & 42 & & $100 \%$ \\
\hline
\end{tabular}

Tabel 1 menunjukkan skor kompetensi sains peserta didik yang mengikuti pembelajaran materi Virus dengan model PBL cederung tinggi, lebih dari 50\% dari seluruh peserta didik memperoleh skor pada rentang 90-100. Dengan skor paling rendah 40 dan skor tertinggi 100 , diperoleh nilai rerata kompetensi sains sebesar 87,5 pada kelas dengan model PBL. Sebagai perbandingan berikut adalah hasil skor literasi sains pada peserta didik yang belajar materi Virus dengan model CL-STAD.

Tabel 2. Distribusi frekuensi skor capaian aspek kompetensi sains peserta didik dengan model CL-STAD

\begin{tabular}{cccc}
\hline Interval Skor Kompetensi Sains & Jumlah Peserta didik (frek) & Frek kumulatif & Persentase \\
\hline $0-13$ & 5 & 5 & $12 \%$ \\
$14-27$ & 1 & 6 & $2 \%$ \\
$28-41$ & 2 & 8 & $5 \%$ \\
$42-55$ & 7 & 15 & $17 \%$ \\
$56-68$ & 18 & 33 & $43 \%$ \\
$69-82$ & 9 & 42 & $21 \%$ \\
\hline Total & 42 & & $100 \%$ \\
\hline
\end{tabular}

Secara umum, capaian skor kompetensi sains pada kelompok peserta didik dengan model CL-STAD cenderung lebih rendah, $12 \%$ dari seluruh peserta didik bahkan hanya memperoleh skor dibawah 13. Skor kompetensi sains siswa paling rendah adalah 0 dan skor tertinggi 82 , serta rerata skor 52 . Hanya $21 \%$ yang mencapai skor 69-82. Sebagian besar memperoleh skor pada rentang 56-68, sehingga, ditinjau dari nilai rata-rata, memperlihatkan bahwa skor kompetensi sains peserta didik dengan model PBL lebih tinggi dibandingkan CL-STAD (87,5 dan 52). Selanjutnya, untuk mengetahui apakah perbedaan tersebut signifikan, dilakukan analisis statistik inferensial.

Pengujian normalitas menghasilkan nilai signifikan Kolmogorov-Smirnov 0,009 < 0,05 dan nilai signifikan Shapiro- Wilk untuk kelas PBL 0,000 < 0,05 dan kelas CL-STAD 0,102 > 0,05 dan 0,236 > 0,05 pada uji KolmogorovSmirnov dan Shapiro Wilk, hal ini berarti untuk kelas PBL nilai literasi sains tidak berditribusi normal sedangkan untuk kelas CL- 
STAD berdistribusi normal. Namun karena kelas PBL tidak berdistribusi normal maka uji parametrik (uji t) tidak bisa digunakan untuk menguji perbedaan rata rata nilai literasi sains peserta didik di SMA 1 karena salah satu syarat uji $t$ adalah nilai pada variabel masing-masing kelompok berdistribusi normal.

Uji homogenitas dilakukan dengan menggunakan uji Levene's. Nilai Levene ditunjukkan pada baris nilai berdasarkan mean yaitu 0,379 dengan nilai signifikan 0,540 > 0,05 , hal ini berarti terdapat kesamaan varians antara kelas PBL dan kelas CL-STAD, dengan kata lain kedua kelas tersebut homogen. Analisis dilanjutkan dengan menggunakan uji statistika non parametrik Mann Whitney.

Hasil uji Mann Whitney menunjukkan nilai signifikan $0,000<0,05$, hal ini menunjukkan bahwa ada perbedaan signifikan peringkat rata-rata skor kompetensi sains peserta didik kelas X IPA dengan model PBL dibandingkan pembelajaran model CL-STAD. Capaian kompetensi sains peserta didik cenderung lebih tinggi secara signifikan saat dibelajarkan melalui model pembelajaran PBL.

Proses pembelajaran yang dilakukan perserta didik dari dua kelas menjadi penyebab perbedaan capaian kompetensi literasi sains. Dalam pelaksanaannya, model PBL dilakukan secara berkelompok dalam 6-8 orang peserta didik yang kemudian diberikan suatu masalah untuk didiskusikan solusinya. Materi virus merupakan materi ajar biologi yang sangat relevan dengan prinsip pelaksanaan PBL, di mana dalam konten ini banyak sekali isu-isu yang dapat diangkat menjadi konteks permasalahan dalam kehidupan nyata sehingga memungkinkan peserta didik mengembangkan kemampuan pemecahan masalah. Isu-isu nyata dalam lingkup nasional dan global mengenai penyebaran virus yang menyebabkan penyakit tertentu, menjadi orientasi arah diskusi peserta didik sekaligus menjadi masalah yang harus didiskusikan solusinya. Langkah-langkah PBL yang diterapkan meliputi: orientasi pada masalah, pengorganisasian kelompok belajar, melakukan penyelidikan, menyajikan hasil karya, dan analisis/ evaluasi proses penyelesaian masalah. Peserta didik melalui LKS diarahkan untuk menyelesaikan permasalahan yang diajukan guru yang berbeda setiap kelompoknya serta diminta untuk menghasilkan karya sebagai hasil pemikiran menyelesaikan masalah yang ada (dalam bentuk poster sederhana).

Meninjau perbedaan proses pembelajaran yang berlangsung dalam PBL dan CL-STAD, terdapat perbedaan mencolok, yaitu dalam PBL dikarenakan peserta didik diarahkan untuk memberikan solusi permasalahan, maka dalam prosesnya peserta didik juga ditugaskan untuk membaca berbagai referensi yang relevan dengan masalah yang dipaparkan. Kondisi ini sejalan dengan hasil penelitian Finneran (2017), yang menemukan bahwa kegiatan membaca tulisan ilmiah mampu mendorong berkembangnya kemampuan literasi sains peserta didik. Dalam proses pemecahan masalah, membaca tulisan saintifik menjadi salah satu proses yang penting sehingga peserta didik dapat mengasah kemampuan berpikir kritis dan kreatif untuk mengajukan solusi masalahnya. Dalam pembelajaran CL-STAD, proses membaca ini yang kurang terfasilitasi dikarenakan peserta didik kurang difasilitasi untuk berpikir mendalam selain mengerjakan tugas kelompoknya.

Topik permasalahan sebagai ciri dalam memulai pembelajaran model PBL juga menjadi pembeda dengan model CL-STAD. Proses pembelajaran mengenai Virus diawali dengan meminta peserta didik berpikir aktif menanggapi masalah virus HIV yang sampai sekarang masih relevan untuk dibahas dalam pembelajaran. Masalah factual seperti ini menarik minat peserta didik untuk bertanya dan berpikir lebih banyak mengenai topik bahasan. Sejalan dengan saran yang diajukan 
Grant dan Dianne (2011) bahwa literasi sains dapat ditingkatkan dengan melakukan beberapa strategi, yaitu: guru mengidentifikasi topic yang menarik, guru mendorong peserta didik untuk membaca hasil penelitian, guru mengajari peserta didik untuk membaca sebagaimana ilmuwan, dan guru membimbing peserta didik untuk menganalisis data. Dalam pembelajaran bermodel PBL yang dilakukan, keempat strategi yang disarankan terintegrasi ke dalam langkah-langkah PBL. Di sini dapat dipahami mengapa PBL memberikan perbedaan signifikan terhadap capaian kompetensi sains peserta didik. Hasil yang sama ditunjukkan oleh penelitian di pendidikan tinggi bahwa implementasi model pembelajaran PBL meningkatkan kemampuan literasi sains secara signifikan (Fauzan et al, 2017). PBL juga diketahui mendorong peserta didik untuk terlibat dalam pembelajaran aktif dan mendalam, tidak hanya memahami konten ilmu, namun juga menguasai konteks yang terkait dengan permasalahan sehari-hari (Wood, 2004).

Tes capaian kompetensi sains yang dilakukan mengacu kepada tiga kompetensi sains dalam literasi sains yaitu kemampuan mengidentifikasi isu-isu ilmiah, kemampuan menjelaskan fenomena secara ilmiah, dan kemampuan menggunakan bukti-bukti ilmiah. Berikut adalah carta perbandingan capaian tiap aspek pada kelas PBL dan CL-STAD.

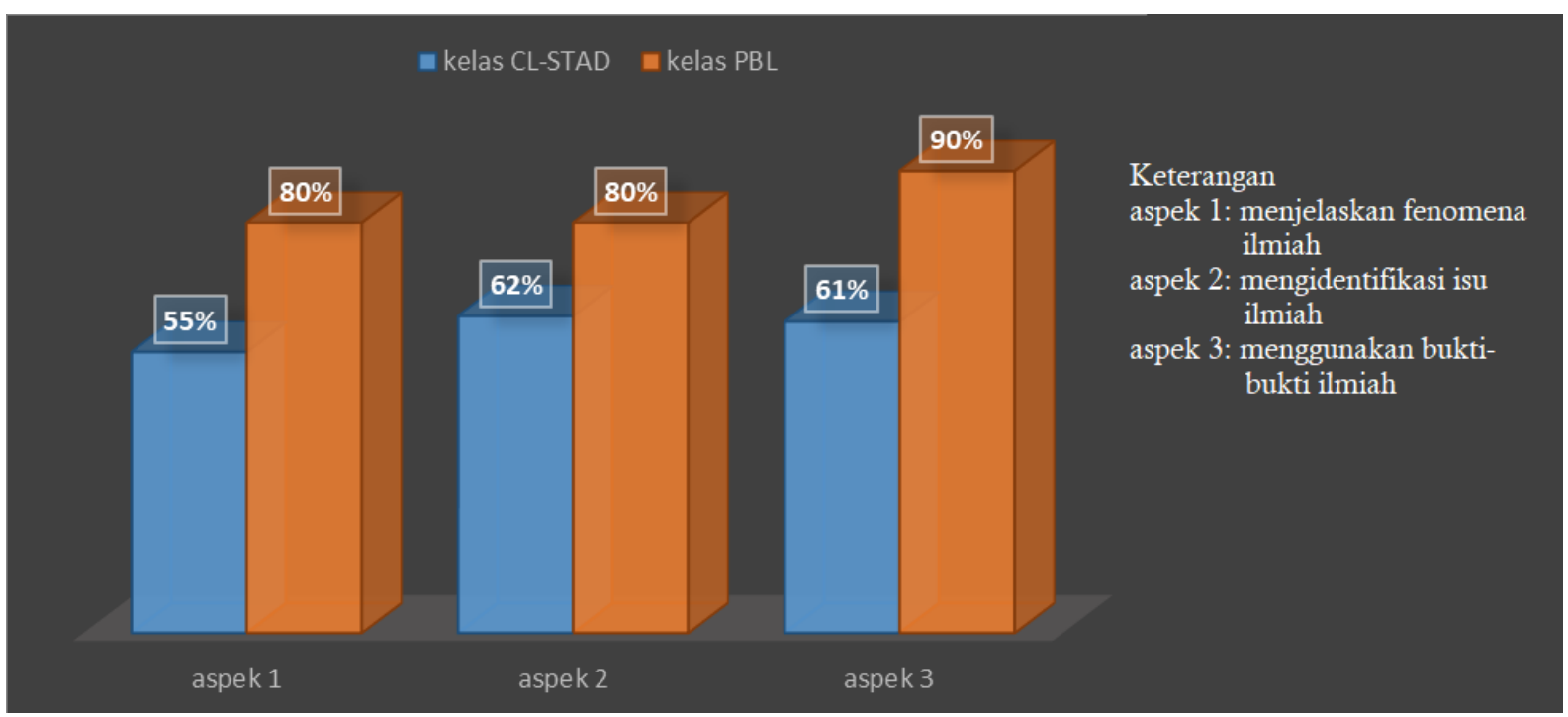

Gambar 2. Diagram perbandingan capaian tiap aspek kompetensi sains pada kelas PBL dan CL-STAD

Capaian tiap aspek pada kelas CL-STAD berkisar antara skor 55 sampai 62, dan pada kelas PBL berkisar antara 80 sampai 90. Peserta didik dengan model PBL memiliki capaian tertinggi pada aspek menggunakan bukti-bukti ilmiah. OECD (2013) menjelaskan bahwa aspek kompetensi merupakan jembatan antara aspek konteks dan aspek pengetahuan dalam mengembangan literasi sains peserta didik. Domain konteks diberikan sebagai materi stimulus bagi peserta didik, aspek kompetensi sains menunjukkan tanggapan peserta didik terhadap suatu pertanyaan atau isu yang disajikan, sedangkan pengetahuan sains merupakan inti dari konten yang disajikan.

Salah satu indicator dalam soal tes adalah peserta didik memberikan penjelasan tentang fenomena zoonosis dalam penyebaran virus serta mengajukan contohnya. Peserta didik yang belajar dengan model PBL cenderung 
mampu lebih baik dalam menguraikan jawabannya, dikarenakan dalam model PBL mereka sudah dituntut untuk banyak membaca dan berpikir secara kritis membandingkan fenomena zoonosis yang satu dengan yang lain. Pada aspek menggunakan bukti-bukti ilmiah, diberikan soal berkaitan dengan grafik fluktuasi penderita penyakit MMR yang disebabkan virus. Menggunakan data pada grafik, peserta didik di kelas PBL cenderung mampu memberikan interpretasi data dengan baik dibandingkan peserta didik pada kelas CLSTAD. Berkaitan dengan isu-isu ilmiah, disajikan soal berkaitan cara memperlakukan penderita HIV (ODH). Peserta didik diminta menelaah apa yang boleh dan tidak boleh dilakukan bersama (ODH). Hasil yang sama, yaitu jawaban lebih baik dan lengkap oleh peserta didik dengan PBL.

Pembelajaran dengan model PBL yang memaparkan peserta didik pada masalahmasalah factual, baik local, nasional, ataupun global melatih peserta didik untuk berpikir kritis melalui fenomena, isu, dan data untuk memberikan solusi permasalahan. Sebaliknya, dalam pembelajaran CL-STAD, peserta didik masih terbatas fokusnya pada aktivitas berkelompok membahas materi diarahkan dengan LKPD yang berfokus kepada konten. Inilah mengapa untuk ketiga aspek kompetensi tersebut peserta didik memiliki capaian yang tingi dibandingkan pembelajaran CL-STAD.

\section{KESIMPULAN}

Berdasarkan temuan penelitian disimpulkan bahwa capaian kompetensi sains pada tiga aspek yaitu, mengidentifikasi isu-isu ilmiah, menjelaskan fenomena ilmiah, dan menggunakan bukti ilmiah, memiliki perbedaan signifikan pada peserta didik yang belajar dengan PBL dan CL-STAD. Model PBL memfasilitasi tercapainya kompetensi sains dengan lebih baik, sehingga hasilnya lebih tinggi dibandingkan model CL-STAD. Model
PBL memfasilitasi tercapainya kompetensi sains melalui proses pemecahan masalah yang diawali dengan mengidentifikasi masalah, mengumpulkan data melalui membaca tulisan ilmiah dan memberikan solusi terhadap masalah. Aktivitas belajar kelompok mempelajari konten keilmuan tanpa ditugaskan untuk menelaah masalah-masalah faktual kurang dapat memfasilitasi berkembangnya kompetensi sains.

\section{UCAPAN TERIMA KASIH}

Ucapan terimakasih disampaikan kepada LP3M UMRAH yang telah mendanai penelitian ini sehingga dapat dilaksanakan dan diselesaikan sebagaimana mestinya.

\section{DAFTAR PUSTAKA}

Aryulina, D. dan Riyanto. (2016). A Problem-based Learning Model In Biology Education Courses to Develop Inquiry Teaching Competency of Preservice Teachers. Cakrawala Pendidikan, 35 (1), 47-57.

Fauzan, M., Gani, A., \& Syukri, M. (2017). Penerapan Model Problem Based Learning Pada Pembelajaran Materi Sistem Tata Surya Untuk Meningkatkan Hasil Belajar Peserta Didik. Jurnal Pendidikan Sains Indonesia, 5 (1), 27-35. https://doi.org/10.15713/ins.mmj.3

Finneran, M. L. (2017). Improving Scientific Literacy through Reading Strategies: An Action Research Study Doctoral dissertation. Retrieved from https://scholarcommons.sc.edu/etd/4346

Grant, M., \& Fisher, D. (2011). Teaching Science Literacy. Publication of Educational Leadership, 68 (6). Retrieved from http://www.ascd.org/publications/educational -leadership/mar11/vol68/num06/TeachingScience-Literacy.aspx

Heller, M. (2005). Topic of interest-Scientific literacy in Latin America: How are we doing? Educational Portal of the Americas. Retrieved from

https://www.educoas.org/Portal/en/tema/tint eres $/$ temaint55. aspx? culture $=$ en\&navid $=36$.

McDonald, J; \& Dominguez, L. (2005). Moving from Content Knowledge to Engagement. Journal of College ScienceTeaching, 35(3), 18-22. Retrieved

from 
https://www.questia.com/read/1G1-

138661833 /moving-from-content-knowledge-toengagement

McPhearson, P.T.; Pollack, G.R.; and Sable, J.E. (2008). Increasing Scientific Literacy in Undergraduate Education: A Case Study from "Frontiers of Science" at Columbia University. Retrieved from https://www.biology.columbia.edu/people/pol lack

OECD. (2013). PISA 2012 Assessment and Analytical Framework: Mathematics, Reading, Science, Problem Solving and Financial Literacy, OECD Publishing. http://dx.doi.org/10.1787/9789264190511-en.

Ogunkola, B. J. (2013). Scientific Literacy: Conceptual Overview, Importance and Strategies for Improvement. Journal of Educationai and Sociai Research, 3 (1), 265-274. https://doi.org/10.5901/jesr.2013.v3n1p265
Scleicher, A. (2019). PISA 2018; Insight and Interpretation. OECD. Retrieved from https://www.oecd.org/pisa/PISA $\% 202018 \% 20$ Insights\%20and\%20Interpretations\%20FINAL \%20PDF.pdf

Strobel, J., \& van Barneveld, A. (2009). When is PBL More Effective? A Meta-synthesis of Metaanalyses Comparing PBL to Conventional Classrooms. Interdisciplinary Journal of ProblemBased Learning, 3(1), 45-58. https://doi.org/10.7771/1541-5015.1046

Sugiyono. (2017). Metode Penelitian Kuantitatif, Kualitatif, dan R\&D. Bandung: Alfabeta, CV.

Wood, E. J. (2004). Problem-Based Learning: Exploiting Knowledge of how People Learn to Promote Effective Learning. Bioscience Education, 3(1), $1-12$. https://doi.org/10.3108/beej.2004.03000006 